\title{
Chapter 7. The Transformation of Progenitor Lines of Origin: Patterns of Precedence in Eastern Indonesia
}

\author{
James J. Fox
}

\section{Introduction}

This paper forms part of an extended argument that is concerned with ideas of origin and precedence among Austronesian-speaking populations (Fox 1988a, $1989,1990,1994,1995)$. It examines the way in which culturally specific ideas of origin give rise to different forms of social precedence in a number of societies in eastern Indonesia. As such, the paper is also concerned with comparison. It explores, within a particular region, the possibilities of comparison among societies that share a common heritage of ideas - in this case, expressed in terms of related concepts of origin.

The context for this argument was set forth in the paper, "Models and Metaphors: Comparative Research in Eastern Indonesia", which constituted my concluding comments to The Flow of Life. In that paper, I argued for a wider Austronesian framework for the comparative consideration of the societies of eastern Indonesia. Although eastern Indonesia may contribute a great deal toward the reconstruction of a model of a proto-Austronesian social world, nevertheless the region represents only one area of a vast Austronesian world. On methodological grounds, sound lexical construction must be based on a whole range of evidence from the entire Austronesian language area (Fox 1980:328-329). Thus F.A.E. van Wouden's inspired attempt $(1935,1968)$ to give a privileged position to the evidence from the societies of eastern Indonesia for the construction of a model of ancient Indonesian society was inevitably suspect because of the regional limits he himself set for his particular attention. Moreover, by concentrating on a particular "model" based on a structural core of formal constructs, van Wouden focused attention on certain characteristics of marriage alliance that have since become an emblem for distinguishing eastern Indonesia from the rest of the Austronesian world. As a result, eastern Indonesia may appear to stand apart from the rest of the Austronesian world.

In the paper on "Models and Metaphors", I went on to argue that the tendency of recent ethnographic research in eastern Indonesia was to study each society from within and in terms of its own social categories:

Research on the social categories of particular societies has not tended to dispel the notion of a structural core but rather to reinterpret it. Instead 
of relying on a formal model consisting of predefined elements, researchers have begun gradually to redefine a structural core in terms of a common set of shared social categories (1980:330-331).

This shift from a study of models to a study of social metaphors provides a better linguistic basis for comparative analysis. Without diminishing the distinctiveness of the region it may also allow the means of interpreting the evidence of the region within a wider framework. The task is to reinterpret this regional evidence systematically but in such a way as to permit comparison with other Austronesian societies.

Finally, in the same paper, I argued specifically that adopting an analysis of the distinctive social categories that constitute the "idiom of alliance" in eastern Indonesia would "eventually alter the conceptual status and relevance of van Wouden's most important analytic categories - those of wife-giver and wife-taker" (1980:332). To this end, I provided several examples of the distinct social categories from different societies in eastern Indonesia that were glossed by different ethnographers as "wife-giver" or "wife-taker". I also pointed to the recurrent use of a botanic idiom and of particular cognates of the Austronesian term for "trunk", "root", "base" or "origin" in the metaphoric conceptualization of alliance relations.

It is to these issues that I wish to return in this present paper. However, I want to attempt to do more than offer a linguistic exegesis of a set of related social categories. Rather I would like to advance a corresponding sociological analysis based on the concept of precedence.

\section{Precedence in Eastern Indonesia}

Precedence is an oppositional notion based on the assertion of a relational asymmetry. It is thus a socially-asserted claim to difference that generally involves an affirmation of some form of "superiority" and/or "priority". As a relational assertion, it is invariably applied recursively to create a concatenation of relationships. Recognizable concatenations of such relationships may be distinguished as "lines" or "orders" of precedence (Fox 1994). The study of precedence requires that attention be focused on: 1) the categorical bases for the assertion of precedence; 2) alternative, competing claims to precedence among groups and individuals; and 3) the consequence of the social competition for precedence.

In eastern Indonesia, precedence is linguistically constructed by recourse to any of a variety of complementary categories (such as male/female, elder/younger, first-born/last-born, inside/outside, prior/later, or trunk/tip). These categories serve as linguistic "operators" that are asymmetrically marked and recursively applied (Fox 1989). Unlike the Dumontian notion of hierarchy based as it is on a single-valued all-encompassing relationship, precedence is structurally relative, 
temporally contingent, and often disputed. Different operators may be invoked to create alternative forms of precedence. Precedence may serve as the means for establishing rank; but it is not the equivalent of hierarchy. Based on differentiation, precedence may be used to create or to undermine what are generally regarded as "hierarchical structures" (Fox 1990, 1994).

Using this concept of precedence, I would like to reexamine the formal categories designated as "wife-giver" and "wife-taker" in eastern Indonesia. As formal categories, they correspond to no single set of identifiable native categories in these different societies. One of my intentions in this paper is therefore to survey those categories that are in fact "translated" as "wife-giver" and "wife-taker". I want to consider these categories as they are used within each society and to consider the relationships that they define.

\section{The Concept of Origin Group: Genitor and Progenitor}

An analysis based on the concept of precedence must be linguistically grounded in terms of the categories used to create that precedence. Discussion of the categories glossed as "wife-giver" and "wife-taker" in eastern Indonesia opens up an elaborate metaphoric epistemology of origins, itself a reflection of a distinctive Austronesian view of life. In accord with this view of life, various social groups in eastern Indonesia (and elsewhere among Austronesian-speaking populations) may appropriately be regarded as "origin groups" since what they claim to share and to celebrate is some form of common derivation. This derivation is socially constructed and may be variously based on the acknowledgement of a common ancestor, a common cult, a common name or set of names, a common place of derivation, and/or a share in a common collection of sacred artefacts. In eastern Indonesia, comparative sociology begins with a study of these "origin groups" and their relationships to one another.

There is a comparative linguistic aspect to this comparative sociology in that both notions "origin" and "relationship", are expressed in similar sets of idioms, frequently (but by no means exclusively) based on botanic metaphors. Understanding these idioms and their use as discourse provides an initial basis for understanding relations among groups.

For the purposes of this paper, as an initial approach in keeping with the idioms that I am attempting to explore, I would like to distinguish between "genitor" and "progenitor". All "origin groups" in eastern Indonesia perpetuate themselves by reference to either "genitor" or "genetrix" lines of derivation. ${ }^{1}$ Internal relations among these lines, which share a common origin, are based on various forms of precedence, such as elder/younger, male/female, inside/outside, first-born/last-born. Relationships between different origin groups, however, are structured on other criteria of precedence. Origin groups generally acknowledge and give precedence to a "progenitor" line (or lines). By 
this, I mean a line (or lines) that stand in relation to a genitor/genetrix line as "life-giving" pro(to)-genitor. This relationship is critical - particularly in an epistemology of origins - since this line is the "origin of life" for another origin group.

Exploration of these notions is a complex task and this paper provides only a bare sketch of aspects of these notions. One of the most interesting features of this exploration is that societies with origin groups based on genetrix lines are not simply a mirror image of societies with origin groups based on genitor lines. It is this feature that I wish to examine after sketching the outlines of a number of societies based on genitor-progenitor relations.

My initial task is to identify such lines in a number of different societies so as to make clear what it is that I mean by the relationship genitor/progenitor. My second task is to examine how such lines function in these different societies, thus setting the stage for consideration of how these relationships may be transformations of one another.

In this paper, I want to consider progenitor relations of origin in six separate societies of the Timor and Flores area. These societies are: 1) the Mambai, 2) the Ema, 3) the Rotinese, 4) the Timorese or Atoni (Pah) Meto, 5) the Tetun of Wehali, and 6) the Ata Tana 'Ai. The languages of these societies are relatively closely related and all are classified as belonging to the putative "Timorese subgroup" of Central Malayo-Polynesian. Linguistic similarities among these languages facilitate examination of the epistemology of social practice.

I begin therefore with the mustering of the basic evidence for my argument.

\section{The Mambai}

The Mambai of East Timor provide an appropriate starting point for this analysis since the notions I wish to examine have already been brilliantly highlighted by Elizabeth Traube in her monograph, Cosmology and Social Life (1986) and particularly in her paper, "Obligations to the Source" (1989).

The Mambai constitute a population of approximately 80,000 living in dispersed hamlets in the mountainous area of east central Timor. The Mambai, who rely mainly on the swidden cultivation of maize, rice and root crops, do not have centralized villages. Hamlets consist of small groups of houses ( $\mathrm{fada}$ ) which function as minimal lineages. Houses are divided into a large number of cult groups (lisa) each of which shares a common cult house (fad lisa) and serves as the locus for ceremonial activity. These cult groups are in turn organized into a "great cult" (lis $t u$ ) whose house constitutes the "stem house" or "house of origin" (fada ni fun). Several great houses may share a single hilltop site with each huge house arranged in a circle around a round stone altar at the centre of which stands a three-pronged ritual post. 
Various idioms are used to describe cult relations. Members of a great cult are elder/younger (kak-alin) to one another. The great cult house is "mother and father" (inan nor aman) and the lesser houses are its children (anan). Alternatively, these lesser cult houses are the "twigs" (snikin) established by a younger sibling who "plucks a leaf//breaks a branch", selects a rock and a sacred object and sets out to found his own separate house. The scattered children of a great house are supposed to unite periodically at their "source" or "origin" (fun). The organization of this kind of origin group is traced through males and is supposed to be exogamous. These houses that recognize a common "house of origin" form a single "origin group" based on "genitor" lines.

Among the Mambai, each origin group recognizes two progenitor houses (or lines). Collectively, these primordial progenitors are referred to as umaen fun (lit., "male houses of trunk or origin") or nai fun (lit., "mothers' brothers of origin"). Alternately, these lines are distinguished as "mother water buffalo and father water buffalo" (arabau inan nor arabau aman). The "father water buffalo" designates the earliest progenitors; the "mother water buffalo" the subsequent progenitors. Together these progenitor lines are described as "those who support the rock//those who steady the tree". As Traube makes clear, this botanic idiom is pervasive:

Symbolically, the original "trunk" givers of women are the source of all persons engendered in the wife-taking house, and they are linked through the daughters of their daughters to still other wife-taking houses. As the Mambai say of marital alliance: "Its trunk sits there. The bits of its tip go out again and again" (1986:86).

From the perspective of the progenitor lines, the lines they engender are referred to in various ways. In contrast to their own umaen fun (the "male houses of origin"), they are maen heua: lit., "new males", a term which is the kin category for daughter's husband (DH) and sister's child (ZC). In opposition to their nai fun, "mother's brothers of origin" they are the kai akin, "father's sisters (FZ) of long ago".

This primordial relationship between progeny and progenitor is described by the Mambai as "sisters since the base of heaven//brothers since the rim of earth" (tbo hoir lelo fun//nara hoir rai ehan). Here, too, there is the recurrent emphasis on category of fun: "base", "origin", "trunk", "source". Traube adds the important qualification for an understanding of nature of this primordial relationship:

If a man wants to marry a woman from an unrelated house, he must first ask ritual permission of his umaen-fun ("wife-givers of origin" or "trunk wife-givers"). He must pay his umaena for the seita nor aifa ("the torch 
and the fire") to "light the dark path" as he searches for a wife among strangers (1980:353, n.10).

In this way, the primordial relationship of progenitor of origin is retained through the vicissitudes of changing alliances.

\section{The Ema}

The Ema are a population of over 50,000 living in the mountains to the west of the Mambai. Their main subsistence crop is maize but they cultivate both wet and dry rice and maintain terraced fields built on rocky slopes. The Ema speak a language that is closely related to that of the Mambai, though this language does not have the metathesis common in Mambai. They have been described in general and in detail by Brigitte Renard-Clamagirand in an important paper, "The Social Organization of the Ema of Timor" (1980) and in the monograph, Marobo: Une société ema de Timor (1982). Despite a slightly different theoretical terminology, the description of the Ema points to considerable similarities with the Mambai.

The Ema recognize two types of settlement. Ilat land located on the upper slopes of Mount Marobo which is subject to ritual prohibitions and rae mdon which is open land, available as new farm land and free of ritual prohibition. "Core houses" (uma lulin: "sacred house" or umar no apir: "house and hearth") are built on ilat land and oriented to the west. These core houses play a central role in the ceremonial life of various lines of elder/younger ( $k a^{\prime}$ ar-alir) brothers who inhabit dependent houses, designated by different terms depending on their relation to their core. As among the Mambai, elder/younger categories can also be used to designate a relationship between independent core houses that claim a common origin, which is often marked by a shared name (1980:136-139).

These variously named core houses can be regarded as origin groups structured on the basis of genitor lines. There is, however, an aspect to these origin groups that is elaborated much more among the Ema than among the Mambai. Although Traube mentions that there is some relative ranking among great cult houses, this dimension does not appear to be highly developed among the Ema. By contrast, among the Ema, precedence exists not only within core houses but also among core houses. All core houses are divided into two categories: autochthonous core houses and immigrant core houses. The immigrant core houses are derived from three ancestral founders who assumed different functions within the society as a whole. One of these founders established a political dimension to Ema society by giving rise to the three chieftains who rule Marobo.

Like the Mambai, the Ema recognize two progenitor lines that are referred to as uma mane: "masculine houses" or "male houses". (The equivalent Mambai term is elided and metathesized as umaen.) The term, uma mane pun, literally 
"male house(s) of origin" is also used in this connection. The multiple senses of the cognate term, fun/pun, allow a variety of translations for expressions that are clearly related. Thus Traube translates umaen fun as "wife-givers of origin" or "trunk wife-givers" whereas Renard-Clamagirand translates uma mane pun as "base house of the wife-givers". In this paper, I refer to both as "progenitors of origin". These progenitors are also identified as na'ir no tatar, "mother's brothers and ancestors" or sometimes as inar no amar, "mothers and fathers". As among the Mambai, Ema progenitors refer to their engendered lines as mane heu, "new males", who may also be spoken of either as kir no bagir, "father's sisters (FZ) and their husbands (FZH)" or as mtor no anar, "sisters and their children".

The established relationship between progenitor and progeny is described by the expression, ai mea. Although Renard-Clamagirand does not provide a translation for ai mea, a literal rendering of this expression would be the "red tree" or more appropriately, the "dry tree". A careful reading of the ethnography suggests that the Ema oppose the categories mea/mdon, "red/green" or "dry/fresh", implying that what is red or dry is old and set with ritual prohibitions; whereas what is green and fresh, and thus still sprouting, is new and as yet free of ritual injunctions - as, for example, the rae mdon. An appropriate translation of this Ema expression would be "old tree". Certainly the botanic metaphor of a tree is consistent with other Ema expressions for this relationship. Thus the progenitors refer to those engendered by their progeny as their "new male leaves and tree tops" (mane heu tahan no laun).

Although the ai mea relationship is regarded as primordial, Renard-Clamagirand remarks that in fact "the 'ai mea' title does not always correspond to the most ancient ties because when a previously allied group disappears or ties with an allied group are severed, the title is bestowed on another core house" (1980:142).

At this point following a geographical progression, it would be appropriate to consider the case of the Tetun and then that of the Atoni Meto who form the dominant population of West Timor. However, for purposes that will become clear as I present my argument, it is more appropriate to consider next the case of the Rotinese.

\section{The Rotinese}

The Rotinese, who number over 120,000, occupy both the island of Roti, off the west tip of Timor, as well as stretches of West Timor. Since the seventeenth century, Roti has been divided into various separate domains known as nusak that have consistently endeavoured to distinguish themselves from one another. There were seventeen such domains with considerable variation - linguistic, 
social and political - among them. I confine myself here to common cultural features of all the domains.

Each Rotinese domain is composed of a number of named leo which are internally segmented to the level of individual uma. These are the Rotinese origin groups. Residence is scattered and members of different leo live interspersed with one another. All leo acknowledge a shared origin $(h u)$ and formerly, this common heritage was celebrated at an annual Feast of Origin (Hus) performed around a large living tree ringed by rocks. The idea that the leo was once represented by a single cult house persists, especially in parts of West Roti, but in fact, after several centuries of Christianity, leo no longer possess a common ceremonial focus.

The different lines within a leo are described as its branches (ndanak) and precedence among these branches is structured according to relations of elder/younger $\left(\mathrm{ka}^{\prime} \mathrm{a} / \mathrm{fadi}\right)$. Elder generally takes precedence over younger, although in some instances of succession, ultimogeniture overrides precedence by relative age. Thus the "last-born" (mulik) may take precedence over the "firstborn" (uluk). The last-born son, for example, inherits the parental house and the ancestral cult that it houses.

Some leo are divided into named "stomachs" or "insides" (teik); in such cases, the teik rather than the leo is the exogamous group. Teik, in turn, are described as consisting of uma, "houses". Links between uma or between teik within each leo are traced by reference to a succession of patronyms. This reckoning distinguishes the genitor lines of each origin group. They are the structural equivalent of the fada/lisa lines among the Mambai and of the various uma segments among the Ema.

Rotinese society shows greater similarities to the Ema than to the Mambai and indeed Rotinese society has developed and elaborated tendencies that Renard-Clamagirand identifies in Marobo. All leo are either autochthonous leo or immigrant leo, with immigrant leo overwhelmingly predominant — both numerically and socially. In all domains, however, autochthonous leo retain precedence in matters of ritual, particularly rituals of the earth.

In each Rotinese domain - as is the case in Marobo - one immigrant line is the source of political authority and claims precedence over all other leo. This line is the "source" of nobility which is defined by an equation between "rule" and "maleness" (mane = male, lord). This lordly line sets the point in relationship to which status is determined according to a complex system of precedence. The status of all leo - and their segments - is thus politically defined. To exist within the domain, a leo must be recognized by the royal court. This pervasive political dimension to Rotinese society is not a recent phenomenon but can be traced back to the seventeenth and early eighteenth centuries (see Fox 1979a,b). 
The prior "cult" foundation of leo/teik/uma has been transformed within a court framework.

Like the Mambai and Ema, most Rotinese acknowledge two progenitor lines. ${ }^{2}$ They are referred to collectively as the to'o-bai-kala, "mother's brothers and mother's mother's brothers". Specifically, the representative of each of these progenitor lines is identified as the to'o-huk, "mother's brother of origin", and the bai-huk, the "mother's mother's brother of origin". The recognition of progenitors is not acknowledged at the level of the leo nor - except in the case of a few royal lines - at the level of the teik, but only at the level of the uma. This means that progenitors are not regarded as primordial but differ for each sibling group derived from the same mother.

For purposes of comparison, it is worth noting here that the Rotinese have a term for son-in-law or daughter's husband, mane feuk, which literally means "new male". This term is cognate with the Mambai term maen heua and Ema mane heu. However, among the Rotinese, "new male" is not used in a wider sociological sense to define a line of engendered progeny. The female equivalent is "new female", feto feuk, which refers to a daughter-in-law or son's wife.

Among the Rotinese, a progenitor relationship is recreated for each generation. Instead of focusing on the mane feuk, this relationship focuses specifically on the sister's child who is referred to as "plant" (selek) or as the "planted sprout" (sele-dadik). In Rotinese, there is no other "kin term" for sister's child except this designation as "plant" (see Fox 1971).

In this situation, the payment of bridewealth is fundamental to the establishment of a progenitor relationship. Bridewealth (belis) serves as a critical marker of the relationship and the amount of bridewealth paid is an index of the "status" of the progenitor line. However, equally crucial to this relationship is temporality. It is not an enduring relationship. Severance of this relationship is essential to it. Mortuary payments do not simply acknowledge this relationship. At the appropriate point, they formally sever it. Thus the progenitor relationship is explicitly one of short duration. It always exists but it changes in each generation.

The situation can - and does - occur where genitor and progenitor relationships are confounded. This occurs whenever bridewealth is not paid and a woman's child is incorporated in his or her mother's origin group. Rotinese prefer to cast a shroud over occurrences of this kind but they are always made evident when mortuary payments must be made. When a house has no sons and only a daughter, the daughter may be allowed lovers in the hope of giving birth to a son who will continue the male line. This is described as "retaining a sister [for her] to give birth for her father and brother". 
Alternatively a stranger - someone from outside the domain or preferably from another island - may "marry" a daughter of the house and have children who are regarded as children of their mother's origin group. After two generations, the tracing of origins by the recitation of a succession of genealogical names obscures this situation and the names of children of women are assimilated to the male line. The adoption of children, except of children of the closest members of one's own origin group, is rare and is not given social approval.

\section{The Atoni Meto}

The Atoni (Pah) Meto are the dominant population of west Timor. For more than two hundred years, they have steadily expanded westward and northward from the eastern uplands of west-central Timor. Their population now numbers over 750,000 and their social organization shows two modalities that are each the expression of similar organizing principles under different conditions. In one modality, older political centres endeavour to maintain formal relationships established in the past while in another modality, newer settlements establish new relationships as expansion continues.

This sketch derives from various sources: 1) my own intermittent fieldwork in southern Amanuban; 2) the excellent thesis, Narrating the Gate and the Path, by Andrew McWilliam (1989) on the basis of extensive fieldwork throughout Amanuban; 3) the University of Indonesia thesis, Ekologi, persebaran penduduk dan pengelompokan orang Meto di Timor Barat, by Hendrik Ataupah (1992) on the Sonbai area to the north of the Noil Mina; and 4) the "classic" studies of the Atoni by Clark Cunningham (1966, 1967), P. Middelkoop (1931) and H.G. Schulte Nordholt (1971). ${ }^{3}$

Like the Rotinese, the Atoni Meto recognize origin structures of long and of short duration. The Atoni Meto are divided into as many as 400 separate origin groups, each of which is distinguished and identified by the sharing of a common name, kanaf (or in ritual language, kanaf ma bonif). Implied in the possession of this common name is a common origin from an ancestor identified by the term, $u(f)$, which is the metathesized cognate of the terms, $f u / p u / h u$. The place of origin of the first ancestor is generally associated with an unusual rock outcrop, fatu (or in ritual language, fatu ma hau, "rock and tree"). Andrew McWilliam describes this botanic metaphor brilliantly but succinctly:

The Atoni Meto "conceive of the name group in a botanical idiom whereby the founding ancestor is considered the trunk (uf) and his descendants are the small branches (tlaef), the tips (tunaf), or the flowers (sufan). The name group is therefore considered as a tree (hau uf mese one tree trunk) in which there is an unbroken and organic link to the ancestral 'trunk' father" (1989:142). 
Despite their emphasis on a common trunk, individual segments of a kanaf or "name group" exist as fragments scattered over all of west Timor, clustering in greater concentrations in certain areas but still scattered. Certain name groups hold political dominance over particular territories and have gathered other name groups around them in specific ritual relationships. Knowledge of past genealogies is limited. Instead of tracing social origins by means of a succession of genealogical names - as among the Rotinese - Atoni Meto trace their origins spatially as a journey of the kanaf name through a landscape of place names.

The scattering of segments of the kanaf has given rise to the spectacular expansion of the Atoni Meto but it does not of itself provide a basis for the structure of the society. The real genius of the system is the way in which these fragments are structured by means of precedence based on progenitor lines of origin.

Like the Rotinese, the Atoni Meto use the same metaphor of "trunk" to describe origin structures of relatively short duration. Every Atoni settlement must have a kua tuaf who, as lord of the settlement, is referred to as its uf, "trunk" or "origin". In theory, this "trunk" (uf) represents the name group (kanaf) whose original ancestor founded the settlement, the right to do so having either been delegated from a political centre or from a name group with higher authority in the area. To gain admission to the settlement and to rights to land around it, each incoming member of another name group has to secure a relationship to the settlement's "trunk". Those who join a settlement are "those who come wandering" (atoin anao amnemat) or the "strange-eyed [hawk-eyed] people" (atoin mata teme).

A "settlement lord" (kua tuaf) becomes the atoin amaf, "mother's brother", a term which in this context designates the ultimate progenitor of the settlement. Generally a settlement lord establishes his position as progenitor by giving a woman to the first, and possibly the second, in-coming member of a different wandering name-group fragment. These groups, in turn over time, give women to other in-coming name groups so that - in theory - a well-ordered settlement is based on a clear line of precedence emanating from a single $u f$-progenitor. In contrast to the group of the settlement lord, the rest of the settlement are "in-marrying people" (atoin asaot) (see McWilliam 1989:143).

To understand the complexities of this system it is necessary to indicate the complementary categories or operators by which this system is structured. One set of categories is, as might be expected, "earlier"/"later" (nahun/namuni na-hun being based, I believe, on an earlier form of the term, "trunk"). As the settlement lord's group develops, it segments along "elder/younger" (tataf/olif) lines, with the tataf or elder line retaining the institutional position of "mother's brother" (atoin amaf). This means in effect that members of an olif or younger line may marry in ways that do not maintain precedence but do not necessarily 
jeopardize the overall order of precedence in the settlement that is maintained by the elder line. Relations of precedence based on a uni-directional flow of women from the atoin amaf are phrased in terms of the categories of "male/female" (mone/feto). These categories are used as relational terms to define precedence. Progenitors are "male people" (atoin amonet) as opposed to the "female people" (atoin amafet), whom they engender. The term, "new male" (mone $f e^{\prime} u$ ) is also used for sons-in-law and more generally all junior males who have received a woman from a particular group. The atoin amaf as ultimate progenitor of the settlement can be described figuratively as the "male or bull" (mone/keso) of the settlement.

Although there are established areas on Timor where bridewealth is important, in the expanding domain of Amanuban and especially at its southern and western periphery, bridewealth was previously not recognized and now is still only of minor significance. Formerly, a child was returned for the gift of a woman. As a result, any name group but particularly the name group of the settlement lord may include its own returned progeny. By the logic of the system, these returned progeny and their offspring are categorized as "female". Thus a settlement lord's group may have not only "elder/younger" lines but also an internal "female" line. This creates a certain ambiguity. The "male" line of a name group may marry with its internal "female" line. The group as a whole, however, also marries with its initial in-marrying "female" group from which its internal "female" line is often derived. Thus the name group of the settlement lord, in particular, engenders "female" -classified progeny both in the name group to whom it gives women and within itself. In established settlements, these two "female" groups/lines may merge so that it may be difficult to distinguish members of the "female" line of the settlement lord's group from members of the initial in-marrying group who - as is customary in Timorese tradition act on behalf of their progenitor.

Only the directionality of the flow of women determines who is classified as "male" or "female" in this situation. Thus a line of precedence is never permanent. By reversing the direction of marriage, which is possible in the Atoni Meto symmetric marriage system, a name group or a line within such a group can alter its relative position of precedence. "Female" can become "male". This can occur at any position within the progenitor line. Any settlement lord who takes a wife from a female line or from another group in his settlement ceases to be the trunk of the settlement since he must acknowledge his progenitor as the new "trunk" or "origin" of the settlement.

\section{The Tetun of the Southern Plain of Wehali}

To this point, I have considered only societies with origin groups based on genitor lines. The Tetun of Wehali present the exceptionally interesting case of 
a society based on genetrix lines. With its genetrix lines, Wehali is distinguished from the majority of Tetun-speaking peoples who recognize genitor lines.

Wehali is a ritual centre on the south coast of central Timor whose population numbers approximately 40,000. The alluvial plain (fehan) on which Wehali is located stands in contrast to the mountains (foho) where most Tetun live. Wehali is considered rai feto, "female land", as opposed to rai mane, "male land", and is the traditional site of the Maromak Oan who is also described as the Nai Bot, "The Great Lord", or Nai Kukun, "The Dark Lord". To this Lord, tribute was paid by other Tetun for performance of the rituals of life. Two PhD dissertations have been written in the Department of Anthropology at The Australian National University on Wehali: G. Francillon's Some Matriarchic Aspects of the Social Structure of the Southern Tetun of Middle Timor (1967) and G.T. Therik's Wehali, The Four Corner Land: The Cosmology and Traditions of a Timorese Ritual Centre (1995). I have drawn this analysis from these two important studies.

Wehali is regarded by its population as the first dry land to have emerged from a primordial sea. This dry land first emerged in the form of an enormous banyan tree. Thus, as in other Timorese societies, "trunk" (hun) is conceived of, both literally and figuratively, as "origin". Ideas of origin are critical and pervasive in all narratives of the past. The origin narratives of the "earth" (rai lian), as indeed other "true narratives" (lia tebes), are all recited in a form of parallel language which is in fact known as "trunk" or "origin" language (lia hun).

In the first narrative of the earth, the "Only Woman on Earth" gave birth to a daughter whose umbilical cord was intertwined in the roots of the banyan. As she grew, so did the banyan to become dry land. As "trunk", she produced both sons ("fruit": klaut) and daughters ("flowers": funan) shaded by an evergrowing banyan. In local conceptions, Wehali is thus the first-born centre of the earth, its navel and "trunk land" (rai hun) (see Therik 1995:73-76). Settlement is localized and hamlets are classified ritually as either "male" or "female" depending on their ritual functions in relation to the central "female" settlement of the Maromak Oan. By recourse to folk etymology, the shade of the banyan (leon) and the male and female hamlets of Wehali (leo) are symbolically equated.

Conceived of as a female centre, Wehali is regarded as having sent forth its male progeny and to have shed all that is associated with male attributes, including wealth and power. According to a local saying, having given away the "sword", Wehali retains only its "sheath" (Fox 1983:25). This image provides the model for Wehali social life: men are sent forth while women remain to continue the flow of life from the first woman. All order in Wehali is therefore based on genetrix relations. 
Wehali's origin groups resemble those of the other societies we have so far considered. Such groups are based on uma, "houses". An "uma group" consists of a "group formed by one house and its offshoots" (Francillon 1967: 331).

These named "uma groups" are the matrilineages that comprise matriclans known as fukun. Fukun may refer to the group as well as the head of this group, but it also designates "the knot, joint or node" of a stalk of bamboo. Relations within uma-groups (and within fukun) are considered as relations between "elder/younger" sisters (bin/alin), even when, as is often the case, exact genealogical relations between members of the group are unclear. A house or house group can be referred to as inan feton, "mother/sister" and a larger group as ina bin alin, "mother/elder-younger sister". The youngest sister (feto ikun) generally retains occupancy of her mother's house which continues to be the focus of ritual performance. In a large origin group, ritual functions may be divided and coordinated among constituent houses. In relative terms, one's natal house (or "birth place house": uma moris fatik) is regarded as one's origin house (uma hun), and this house serves as the point of reference in the arrangement of marriages.

Houses are exogamous and exchange males among each other. Residence is strictly uxorilocal. From this one might expect that houses would have progenitor relations with one another similar to the other societies that we have so far considered. However, this is not the case. The mane foun, the "new male", simply takes up residence with his wife. The gift of a male is not significant. What is significant is that for every male given to another house, a child, invariably a woman, must be returned. Thus every house receives a share of its own female progeny and engenders differentiation within itself. Every house is also its own progenitor via an intermediate genetrix-house.

The exchange of wealth at the time of marriage is not significant. What is important are subsequent exchanges that begin with the return of "source seed" (mata musan) following immediately on the death of the "new male". A person, either man or woman, can be designated as "source seed" to be returned to the husband-giving house. If the "source seed" is male, he is expected to marry his FZD (talain feto); if female, she is expected to marry her FZS (talain mane).

In practice, "source seed" is invariably a woman. The husband-giving group can delay mortuary ceremonies until their demands for a woman are granted and if no woman is available, then the return of "source seed" may be delayed a generation. The woman eventually given as "source seed" may in fact marry some other in-marrying male rather than her cross-cousin but in whatever way she marries, she and her daughters initiate a new line within the house (Therik 1995:127-130).

This exchange obligation between the two houses continues for a further generation. One of the daughters of the "source seed", preferably the eldest 
daughter, must be given back to the house from which her mother came. ${ }^{4}$ This daughter is referred to as "banana head" (hudi ulun).

Thus each in-marrying male initiates an exchange that entwines two female-centred houses for at least two generations: "like storage baskets tied together or like wax candles that have melted into one" (see Therik 1995:124).

One implication is that progenitor lines in each generation replant new genetrix lines. The exchange of wealth to mark a distinction between genitor and progenitor, as among the Rotinese, does not occur nor is it considered necessary. However, as in Roti, a progenitor line is recognized for three generations back to an initiating "origin house" (uma hun). This line comes to the fore during mortuary ceremonies, particularly in negotiations over "source seed" before burial can take place, and this progenitor line continues for yet another generation to "entwine" the two exchanging houses.

To consider further the implication of this system, it is useful to consider another society like the southern Tetun with origin groups exclusively organized in terms of genetrix lines. This society is that of the Ata Tana 'Ai.

\section{The Ata Tana 'Ai}

Like the Tetun of Wehali, the Ata Tana 'Ai of central east Flores form a "female" enclave centred on the ritual domain of Tana Wai Brama. Within this enclave, a population of approximately 4,500 persons acknowledges a single source and unlike the surrounding population, recognizes genetrix - rather than genitor - lines of origin. E. Douglas Lewis in his recent book, People of the Source (1988), has provided a brilliant and thorough-going analysis of this remarkable society. My purpose here is merely to attempt to sketch elements of this ethnography in order to make comparisons with the other societies - particularly the Tetun - that I have so far considered.

In extending this analysis to this sixth case, we move a further "linguistic distance" from the other societies in this comparison. The Mambai, Ema, Rotinese, Atoni Meto and Wehali Tetun all speak languages that are more closely related to each other than any of these languages is to that of the Ata Tana 'Ai. Similar sociological structures are evident as are the general idioms that describe these structures but specific linguistic cognates, although they exist, are less immediately apparent.

Among the Tana 'Ai origin groups are known as sukun. These groups are appropriately described as "clans". Tana Wai Brama consists of four such sukun plus a central founding sukun, the sukun pu'an. This "source clan" presides over an order of precedence among the constituent clans that is believed to have been maintained since the founding of the domain. 
Sukun are, in turn, divided into houses (lepo) consisting of consanguineally-related women (and their brothers). The inheritance of land, possessions and ritual rights passes from mother to daughter. Lepo, too, are ordered by precedence based on the categories of "elder/younger" (wue/wari) sister. There is a lepo pu'an, "source house", in each sukun. This is the highest ranking house in order of precedence within the sukun.

Men pass between lepo. As among the southern Tetun, an exchange of wealth at marriage does not occur. In a certain sense, marriage itself is not significant. It is not marked as a special event. There is no exchange or formal ceremony. What is marked, however, as among the southern Tetun, is the return of a child of a man who has served as progenitor in another lepo. This is referred to as the return of the "father's forelock" (ama 'lo'en) and is described as the return of the "father's blood". This exchange is marked by the payment of wealth in the form of a fixed quantity of elephant tusks and gongs (to'o-balik). This is, in some ways, the equivalent to "bridewealth" in societies such as Roti. Those who make the payment are called "the mother and father who buy and pay" (ina ama baha boter). Instead of creating a progenitor relationship of the sort that bridewealth establishes, this payment plants a new genitrix within the order of precedence of the sukun. A woman who is returned in this fashion is called an "ancestral mother" (ina puda) and she is seen as the founder of a new house in the clan. Again, as among the southern Tetun, such a woman may marry her FZS who is referred to as "elder" (wue) in a wue/wari relationship. 5 "

Initially, the woman given as "father's forelock" and her descendants are tudi manu, "knife chicken" to the house that paid the wealth for her. This status is altered only when they in their turn pay to'o-balik to obtain the return of a "father's forelock" and thus become ina ama baha boter in their own right.

Exchanges do not end at this point. An ina puda line continues to acknowledge as sukun pu'an, "source clan", the clan from which their "ancestral mother" originated. Four generations later this line is supposed to return a woman (DDDD) "to replant the ancestral mother in the source clan". This woman as mula puda founds a new house in close relationship to the house from which the ina puda originated. She is expected to marry a son of the house of the "source clan" and this group returns half of the to'o-balik they received when the original ina puda was given. This then ends the cycle in which two lepo or their immediate replacement lepo have in the course of four generations each "planted" a woman as genitrix in the other. The botanic markers of relationships of origin are as clearly articulated among the Ata Tana 'Ai as in the other societies of the region.

Perhaps, however, the most significant evidence of the difference in the conception of progenitor lines between a society like Roti (or Sikka) and that of the Ata Tana 'Ai is in the performance of the mortuary ceremonies. On Roti, for example, these ceremonies are the occasion for payments to the progenitor line 
for its essential ritual services. Mortuary rituals can not be performed without the progenitors. In contrast, among the Ata Tana 'Ai, the lepo of the deceased makes all of the arrangements, provides all the goods necessary for burial, and feeds all of the guests - a majority of whom are members of the lepo itself (Lewis 1988:120). Performances, however, require an opposed mutuality and for this purpose, each clan is paired with a clan from another domain. The opposite paired clan comes from outside the domain to perform specific ritual services at the time of burial. The emphasis in these ceremonies is on the integration of the spirit of the deceased into the lepo. On Roti, such ceremonies can not be initiated by an origin group until the last payments for the deceased have been made to the progenitors.

\section{Comment and Conclusion}

This paper has presented a complex comparative argument. Its first purpose was to develop a form of comparative analysis that does not rely on the formal categories such as "wife-giver" and "wife-taker" (or their converse, "husband-giver" and "husband-taker"). The southern Tetun and the Ata Tana 'Ai provide ample evidence of the need to develop a different comparative framework. The use of the notions of progenitor and origin are intended to approximate conceptions that societies which I have considered, hold of themselves. The clues to these conceptions are indicated by the recurrent use of common botanic ideas of origin.

The first step in a comparative analysis of these societies is to note that all of them rely on "elder/younger" categories to distinguish genitor or genetrix lines and to order precedence among such lines. This is a common feature of societies of eastern Indonesia where such relative age categories are applied between same sex siblings and marks an important contrast with other Austronesian societies where such categories are applied both among same sex and opposite sex siblings.

Relative Age Categories: Genitor and Genitrix Lines

\begin{tabular}{lll}
\hline Mambai & Kak-Ali & Genitor lines \\
Ema & Ka'ar - Alir & Genitor lines \\
Rotinese & Ka'a - Fadi & Genitor lines \\
Atoni Meto & Tataf - Olif & Genitor lines \\
Wehali Tetun & Bin - Alin & Genitrix lines \\
Ata Tana 'Ai & Wa'e - Waro & Genitrix lines \\
\hline
\end{tabular}

There is more to this use of relative age categories among same sex siblings. As is evident among the Ata Tana 'Ai, "elder/younger" categories may also be applied to cross-cousins to designate potential spouses. Relative age categories can thus occur both in a marked and in an unmarked form, a feature which is widespread in Austronesian-speaking societies. In various eastern Indonesian 
societies where relative age terms are used to refer to same sex siblings, when these terms are applied between members of the opposite sex, they mark out the "marriageable category" of cross-cousins for purposes of directed marriages. Similarly, where the use of relative age terms is not confined exclusively to same sex siblings, as is the case among Javanese or Malay-speakers, these marked forms are used as intimate terms of endearment between a husband and wife or between lovers.

Proceeding further in a comparative analysis of these six societies, we may consider the various cases as relevant pairs as a means to identify commonalities and differences among them.

All of the societies with genitor lines recognize clearly defined progenitors. The Mambai and the Ema recognize two progenitor lines that are ritually fixed. They are conceived of as primordial and the establishment of relationships with other progenitors is mediated through these lines. These primordial progenitors provide the ritual services for those whom they have engendered. In contrast, the Rotinese, who acknowledge a two-generation line of progenitors, establish new lines for each generation of siblings. Bridewealth is essential to the creation of these lines and mortuary payments affirm and eventually serve progenitor relationships. On Roti, these progenitors of short duration perform the necessary rituals for those whom they have "planted". Among the Atoni Meto of Amanuban, progenitor lines are used as the primary mechanism for structuring new settlements. The progenitor line established by the head of a settlement provides a system of order for the settlement as a whole. A progenitor line of this sort is as precarious as the stability of a settlement.

Idioms of Origin: Progenitor Lines and their Progeny

\begin{tabular}{lll}
\hline \multicolumn{1}{c}{ Progenitor } & \multicolumn{1}{c}{ Progeny } \\
\hline Mambai & Umaen Fun & Maen Heua: \\
& "Male Houses of Origin" & "New Males" \\
& Nai Fun & Kai Akin: \\
& "Mother's Brothers of Origin" & "Father's Sisters of Long Ago" \\
Ema & Uma Mane Pun & Mane Heu: \\
& "Male House(s) of Origin" & "New Males" \\
& Na'ir No Tatar & Kir No Bagir: \\
& "Mother's Brothers and & "Father's Sisters and Their \\
& Ancestors" & Husbands" \\
& Ai Mea & Tahan No Laun: \\
& "Dry Tree" & "Leaves and Treetops" \\
Ro'o-Huk/Bai-Huk & Sele Dadi: \\
& "Mother's Brother/Mother's & "Planted Sprout, Sister's Child" \\
& Mother's Brother of Origin" &
\end{tabular}




$\begin{array}{lll}\text { Atoni Meto } & \begin{array}{l}\text { Uf } \\ \text { "Trunk, Origin" }\end{array} & \begin{array}{l}\text { Tlaef, Tunaf, Sufan: } \\ \text { "Small Branches, Tips, } \\ \text { Flowers" }\end{array} \\ & \text { Atoni Amaf } & \text { Mone Fe'u: } \\ & \text { "Mother's Brother" } & \text { "New Males" } \\ & \text { Atoni Amonet } & \text { Atoni Amafet: } \\ & \text { "Male People" } & \text { "Female People" } \\ \text { Wehali Tetun } & \text { Uma Hun } & \text { Mane Foun: } \\ & \text { "Origin House" } & \text { "New Male" }\end{array}$

The relation of progenitor and progeny is expressed as a relative dyadic relationship rather than, as is commonplace in formal analysis, a tri-partite relationship involving the inclusion of a hypothetical ego-line. The various terms that describe and define this relationship have a similar metaphoric cast among all of the related Timorese language populations. They are phrased in a botanic idiom, often contrast male to female, the mother's brother to the father's sister, or brother to sister, and invariably trace origins from "trunk" to tip. Similar idioms occur among the Wehali Tetun and among the Ata Tana 'Ai, where progenitor-progeny relations are transformed and internalized. Males marry out requiring progeny to be returned to form new origins with the genetrix group.

Marriage sets the pattern of progenitor-progeny relations. ${ }^{6}$ Among the Mambai and Ema, these relations are conceived of as continuing. They are regarded as ancestral and it is essential that they be renewed through further marriages. As such, the directionality of these marriages is maintained. For the Rotinese, new progenitor-progeny lines are created with each marriage. They continue for two generations as "the path of life" from progenitor to progeny but they need not be renewed. Hence the directionality of marriage can shift from generation to generation. Among the Atoni Meto, marriage relations, unless they are institutionalized in ritual forms, are only as stable as particular settlements. Reversing the directionality of marriage changes political relations within settlements.

The payment of bridewealth and the return of progeny are critical to these relations. Among the Rotinese, bridewealth is considered essential for the establishment of a progenitor-progeny relationship. In cases when a woman becomes pregnant but bridewealth is not paid, progenitor and genitor are confounded and various devices are used to obscure the fact that a progeny has been incorporated as part of the genitor group. Among the Atoni Meto, the incorporation of progeny is a common practice. Traditionally, in Amanuban, a child was returned from each marriage as the appropriate payment for the gift of a woman. This returned progeny established a "female" line in relation to the "male" line of the original genitor group. Theoretically over several generations, 
this "female" line had three possibilities: 1) to continue as a "female line" with special ritual authority in the origin group; 2) to replace the "male" by reversing the directionality of marriage - the same mechanism utilized by any subordinate group to replace its superordinate in an order of precedence; or, 3) to sever dependent relations to the "male" line by establishing itself as a new "male" line in another settlement, a mechanism also open to any subordinate group in a settlement.

The Atoni Meto with their practice of returning one child from a marriage provide suggestive comparison with both the Wehali Tetun and the Ata Tana 'Ai where the return of progeny is of critical importance. In both of these societies, the return of a woman in place of her father eliminates any need for the payment of bridewealth. Progenitors thus engender themselves via an engendered group. Among both the Wehali Tetun and the Ata Tana 'Ai, it is evident that whereas a group engenders itself by means of an engendered group, this initial engendered group, at a further generation removed, receives a returned progeny and thus also engenders itself. Following the metaphors of the Ata Tana 'Ai, there occurs a reciprocal "planting" of new genetrix-founders.

This paper offers an initial analysis of progenitor lines of origin and their transformations in several related eastern Indonesian societies. In my sketches of each society, I have endeavoured to attend closely to metaphors of relationship and to follow the implications of what they imply. It is thus possible to see how each of these societies is an expression of a set of common concerns about the nature and continuation of life. ${ }^{7}$

These concerns are not exclusive to eastern Indonesia. They are, rather, a particular expression of ideas found throughout the Austronesian-speaking world. Hence this short paper suggests a form of comparative analysis that might be extended to focus on the transformation of Austronesian ideas of origin and derivation. ${ }^{8}$

\section{References}

Ataupah, Hendrik

1992 Ekologi, persebaran penduduk dan pengelompokan orang Meto di Timor Barat. Unpublished PhD thesis, Universitas Indonesia.

Cunningham, Clark E.

1966 Categories of descent groups in a Timor village. Oceania 37:13-21.

1967 Recruitment to Atoni descent groups. Anthropological Quarterly 40:1-12.

Fox, J.J. 
1971 Sister's child as plant: metaphors in an idiom of consanguinity. In R. Needham (ed.) Rethinking kinship and marriage, pp.219-252. London: Tavistock.

1979a A tale of two states: ecology and the political economy of inequality on the island of Roti. In P. Burnham and R.F. Ellen (eds) Social and ecological systems, pp.19-42. London: Academic Press.

1979b Standing in time and place: the structure of Rotinese historical narratives. In A. Reid and D. Marr (eds) Perceptions of the past in Southeast Asia, no. 4, pp.10-25. Kuala Lumpur: Heinemann Educational Books (Asia) Ltd.

1980 Models and metaphors: comparative research in Eastern Indonesia. In J.J. Fox (ed.) The flow of life: essays on Eastern Indonesia, pp.327-333. Cambridge, MA: Harvard University Press.

1983 The great Lord rests at the centre: the paradox of powerlessness in European-Timorese relations. Canberra Anthropology 5(2):22-33.

1988a Origin, descent and precedence in the study of Austronesian societies. Public Lecture in connection with De Wisselleerstoel Indonesische Studien, given on 17th March 1988. Published, Leiden University.

1988b Foreword to E.D. Lewis, "People of the source: the social and ceremonial order of Tana Wai Brama on Flores", pp.xi-xiv. Verhandelingen van het Koninklijk Instituut voor Taal-, Land- en Volkenkunde No. 135.

1989 Category and complement: binary ideologies and the organization of dualism in Eastern Indonesia. In D. Maybury-Lewis and U. Almagor (eds) The attraction of opposites: thought and society in a dualistic mode, pp.33-56. Ann Arbor: University of Michigan Press.

1990 Hierarchy and precedence. Working Paper No. 3. Comparative Austronesian Project. Department of Anthropology, Research School of Pacific Studies, The Australian National University.

1994 Reflections on "hierarchy" and "precedence". In M. Jolly and M. Mosko (eds) Special Issue of History and Anthropology. Transformations of hierarchy: structure, history and horizon in the Austronesian world, 7(1-4): 87108. Chur and Reading: Harwood Academic Publishers.

1995 Origin structures and systems of precedence in the comparative study of Austronesian societies. In P.J.K. Li, Cheng-hwa Tsang, Ying-kuei Huang, Dah-an Ho and Chiu-yu Tseng (eds) Austronesian studies relating to Taiwan, pp.27-57. Symposium Series of the Institute of History \& Philology: Academia Sinica 3. Taipei.

Francillon, G. 
1967 Some matriarchic aspects of the social structure of the Southern Tetun of Middle Timor. Unpublished PhD thesis, The Australian National University.

Graham, Penelope

1994 Alliance against hierarchy: affinal distinctions and sovereign rights in Eastern Flores, Indonesia. In M. Jolly and M. Mosko (eds) Transformations of hierarchy: structure, history and horizon in the Austronesian world. Special Issue of History and Anthropology, 7(1-4):339-362. Chur and Reading: Harwood Academic Publishers.

Lewis, E. Douglas

1988 People of the source: the social and ceremonial order of Tana Wai Brama on Flores. Verhandelingen van het Koninklijk Instituut voor Taal-, Landen Volkenkunde No 135. Dordrecht: Foris Publications.

McWilliam, Andrew

1989 Narrating the gate and the path: place and precedence in South West Timor. Unpublished PhD thesis, The Australian National University.

Middelkoop, Peter

1931 Gegevens over het Timoreesche Adat-huwelijk. Bijdragen Koninklijk Instituut voor Taal-, Land-en Volkenkunde 88:239-286.

Renard-Clamagirand, Brigitte

1980 The social organization of the Ema of Timor. In J.J. Fox (ed.) The flow of life: essays on Eastern Indonesia, pp.134-151. Cambridge, MA: Harvard University Press.

1982 Marobo: Une société ema de Timor. Langues et Civilizations de L'Asie du Sud-Est du Monde Insulindien No. 12. Paris: SELAF/CNRS.

Reuter, Thomas

1992 Precedence in Sumatra: an analysis of the construction of status in affinal relations and origin groups. Bijdragen tot de Taal-, Land-en Volkenkunde 148:489-520.

Schulte Nordholt, H.G.

1971 The political system of the Atoni of Timor. Verhandelingen van het Koninklijk Instituut voor Taal-, Land-en Volkenkunde No. 60. The Hague: Martinus Nijhoff.

Therik, Gerzon Tom

1995 Wehali: the four corner land: the cosmology and traditions of a Timorese ritual centre. Unpublished PhD thesis, The Australian National University. 
Traube, Elizabeth

1980 Mambai rituals of black and white. In J.J. Fox (ed.) The flow of life: essays on Eastern Indonesia, pp.290-314. Cambridge, MA: Harvard University Press.

1986 Cosmology and social life: ritual exchange among the Mambai of East Timor. Chicago: University of Chicago Press.

1989 Obligations to the source. In D. Maybury-Lewis and U. Almagor (eds) The attraction of opposites: thought and society in a dualistic mode, pp.321344. Ann Arbor: University of Michigan Press.

van Wouden, F.A.E.

1935 Sociale Structuurtypen in de Groote Oost. Leiden: Ginsberg.

1968 Types of social structure in Eastern Indonesia. The Hague: Martinus Nijhoff. [English translation by Rodney Needham.]

\section{Notes}

l Here I intentionally wish to avoid the use of the term "descent" which in eastern Indonesia is often misleading and metaphorically inapt; I also want to avoid special reliance on criteria of genealogical reckoning. Only a few societies - or rather, certain segments within a few societies - in eastern Indonesia insist upon the maintenance of strict genealogical reckoning and it is, in fact, a sociological and historical question why this genealogical reckoning should be so prominent in these particular societies.

2 On Roti there is differential recognition accorded progenitor lines as one moves from east to west. In the east three lines or three generations are recognized; in central Roti, two lines and as one moves to the further western end of the island, only one generation is said to be given full recognition.

3 Part of this sketch has already been presented in Fox $(1994,1995)$.

4 If there is only one daughter from a marriage and therefore no extra woman available to be returned to her father's house, the obligation is, by agreement, continued to the next generation. This is referred to by the expression "to raise the earth, to dam the water" (tate rai halu we). According to Francillon, "these are gardening terms and acts, the significance of which is to invigorate a plant" (1967:363). If ever a mata musan is not returned, it is said that the name of the man who was exchanged is "lost" (1967:364).

5 Quite clearly the Ata Tana 'Ai recognize the implications of their system in comparison with that of the majority Sikkanese population who have a system of bridewealth payments like that of the Rotinese. As an Ata Tana 'Ai explained to Lewis, the Sikkanese "buy wives"; they "buy children" (Lewis 1988:211).

6 In this paper, I have avoided discussing the formal marriage rules of these different societies. If one were to rely on marriage rules as formal criteria for the typological classification of these societies, these societies would be considered differently and the similarities that exist among them might be obscured. Of the six societies I have considered, one or possibly two would be classified as having asymmetric prescriptive alliance; one, symmetric prescriptive alliance while three have no marriage prescriptions but only formally expressed preferences that favour the directionality of marriage.

7 I have already enumerated what I consider to be some of these common concerns in my Foreword to E.D. Lewis' People of the Source (1988:xii). A critical aspect of this concern for the continuation of life involves the aspiration to reunite that which was separated in a previous generation, namely, the sibling pair of brother and sister. The Mambai express this aspiration by conflating space and time and thereby describing the primordial relationship between progeny and progenitor as "Sisters since the Trunk of Heaven//Brothers since the Rim of the Earth".

8 Analysis of these ideas of origin and derivation have already been undertaken by a number of students and colleagues from the Department of Anthropology. In addition to studies already cited and those 
Origins, Ancestry and Alliance

by B. Grimes, E.D. Lewis and M. Vischer in this volume, I would also point to papers by T. Reuter (1992) and P. Graham (1994). 